\title{
EFEK PEMBERIAN KOTORAN AYAM DIKOMBINASIKAN DENGAN AMPAS TAHU TERHADAP PENINGKATAN KUALITAS PERTUMBUHAN Daphnia. sp.
}

\author{
Ma'watun Hasanah ${ }^{1}$, Armen Nainggolan ${ }^{2}$, Firsty Rahmatia ${ }^{3}$ \\ $1,2,3)$ \\ Jurusan Budidaya Perairan FPIK USNI \\ Jln, Arteri Pondok Indah No. 11 Jakarta 12240 \\ mawatunhasanah@gmail.com
}

\begin{abstract}
:
The cultivation of Daphnia magna usually uses fertilization method, both organic and inorganic fertilization. The cultivation of Daphnia magna. Usually done by using chicken manure as a culture medium to grow microorganisms as feed Daphnia magna. In addition to efforts to grow microorganisms as a source of nutrients for Daphnia magna, it is necessary additional protein intake is useful for the population of microorganisms. Protein sources obtained from Tofu dregs. Objectives to be achieved from the implementation of this research are: 1). Know the effect of dosage of manure (chicken manure) with tofu tofu as feed for population growth of Daphnia magna. 2). Knowing the population growth rate of Daphnia magna. 3). Knowing the quality of Daphnia magna as a natural food of fish seed. The research method was chicken dung manure combined with dregs of tofu (22.5 g / l tofu, $7.5 \mathrm{gr} / \mathrm{l}$ of chicken manure), (15 g / l tofu, $15 \mathrm{~g} / \mathrm{l}$ of manure Chickens), $7.5 \mathrm{gr} / \mathrm{l}$ tofu, $22.5 \mathrm{~g} / \mathrm{l}$ of chicken manure), (30 g / 1 of chicken manure), $30 \mathrm{gr} / \mathrm{I}$ tofu ) and without chicken manure and tofu dregs. The results showed that population growth, growth rate and peak population were significantly different between the treatment of chicken manure and tofu dregs. While long growth there is no significant difference between the treatment of chicken manure and tofu dregs.
\end{abstract}

Keywords: Daphnia magna, Chicken Manure, Tofu Dregs, Population Daphni magna. 


\section{PENDAHULUAN}

\section{Latar Belakang}

Daphnia adalah krustasea berukuran kecil yang hidup di perairan tawar, sering juga disebut sebagai kutu air. (Pangkey, H. 2009) Daphnia magna sebagai pakan alami banyak digunakan dalam kegiatan pembenihan ikan. Keunggulan D. magna sebagai pakan alami adalah mudah dicerna oleh benih ikan, tidak menurunkan kualitas air dan memiliki kandungan asam amino esensial yang tinggi kurang lebih $50 \%$ bobot kering (Mokoginta, 2003). Menurut Bogut, et. al., (2010) dalam Putri (2015) kandungan gizi Daphnia magna adalah 39,24\% protein, 4,98\% lemak, 4,32\% karbohidrat, kadar abu 14,63\%.

Budidaya Daphnia magna biasanya menggunakan metode pemupukan, baik itu pemupukan organik maupun anorganik. Biasanya pupuk organik yang lebih bagus digunakan untuk pertumbuhan Daphnia magna. Budidaya Daphnia sp. biasanya dilakukan dengan menggunakan kotoran ayam sebagai media kultur. Di air, kotoran ayam merupakan bahan organik dan juga merupakan media tempat tumbuh fitoplankton dan bakteri, yang ketiganya dapat dimanfaatkan sebagai pakan Daphnia sp (Jusadi, et. al., 2005). Kotoran ayam adalah salah satu jenis pupuk organik yang memiliki nilai kandungan nitrogen dan nutrisi organik yang tinggi dibandingkan kotoran hewan lainnya. Selain usaha untuk menumbuhkan mikroorganisme sebagai sumber nutrisi bagi Daphnia magna, maka perlu adanya tambahan asupan protein yang berguna bagi populasi mikroorganisme.

Sumber protein didapat dari Ampas tahu. Ampas tahu dapat dijadikan sebagai bahan pakan sumber protein karena mengandung protein kasar cukup tinggi berkisar antara 23-29\% (Mathius \& Sinurat, 2001). Maka dari itu penelitian pertumbuhan Daphnia magna dengan menggunakan kotoran ayam yang dikombinasikan dengan Ampas tahu perlu dilakukan. Penelitian ini menggunakan dosis yang berbeda agar menghasilkan kelimpahan populasi Daphnia magna yang optimal.

\section{METODE PENELITIAN}

A. Waktu dan Lokasi Penelitian Penelitian ini telah dilaksanakan di Balai Benih Ikan (BBI) Ciganjur, Jakarta Selatan. Penelitian ini telah dilaksanakan pada bulan Mei sampai bulan Juni 2017.

B. Alat dan Bahan

Alat-alat yang digunakan dalam penelitian ini adalah akuarium, botol sampel, mangkuk plastik, gelas ukur, aerator, selang air, sendok, scoopnet, timbangan digital, Do meter, penggaris, alat tulis, kamera, dan laptop.

Bahan-bahan yang digunakan dalam penelitian ini adalah pupuk kotoran ayam, ampas tahu, air, kertas lael, sampel Daphnia magna, kertas tisu, kertas label dan kain kasa.

C. Rancangan Percobaan

Desain penelitian yang digunakan adalah RAL (Rancang Acak Lengkap) satu factor dengan enam perlakuan dan empat ulangan. 
Perlakuan 1 : tanpa menggunakan pupuk kotoran ayam dan ampas tahu (Tanpa PKAT)

Perlakuan 2 : pupuk kotoran ayam $100 \%=30 \mathrm{gr} / \mathrm{l}(\mathrm{PK})$

Perlakuan 3 : ampas tahu $100 \%=30 \mathrm{gr} / \mathrm{l}(\mathrm{AT})$

Perlakuan 4 : pupuk kotoran ayam $25 \%=7,5 \mathrm{gr} / 1+$ ampas tahu $75 \%=22,5 \mathrm{gr} / \mathrm{l}$ (PKAT 1)

Perlakuan 5 : pupuk kotoran ayam 50\% = $15 \mathrm{gr} / \mathrm{l}+$ ampas tahu 50\% = $15 \mathrm{gr} / \mathrm{l}$ (PKAT 2)

Perlakuan 6 : pupuk kotoran ayam $75 \%=22,5 \mathrm{gr} / \mathrm{l}+\operatorname{ampas}$ tahu $25 \%=7,5 \mathrm{gr} / \mathrm{l}$ (PKAT 3)

\section{HASIL DAN PEMBAHASAN}

\section{A. Pertumbuhan Populasi}

Budidaya Daphnia magna dengan menggunakan pakan mikroorganisme dalam air seperti fitoplankton dan zooplankton yang dihasilkan dari perendaman pupuk kotoran ayam yang dikombinasikan dengan ampas tahu sesuai dosis yang berbeda yang dapat meningkatkan populasi Daphnia magna. Hasil pengamatan tingkat pertumbuhan populasi Daphnia magna selama penelitian ini dapat dilihat pada Tabel 1.

Tabel 1. Pertumbuhan Populasi Daphnia magna per lima hari

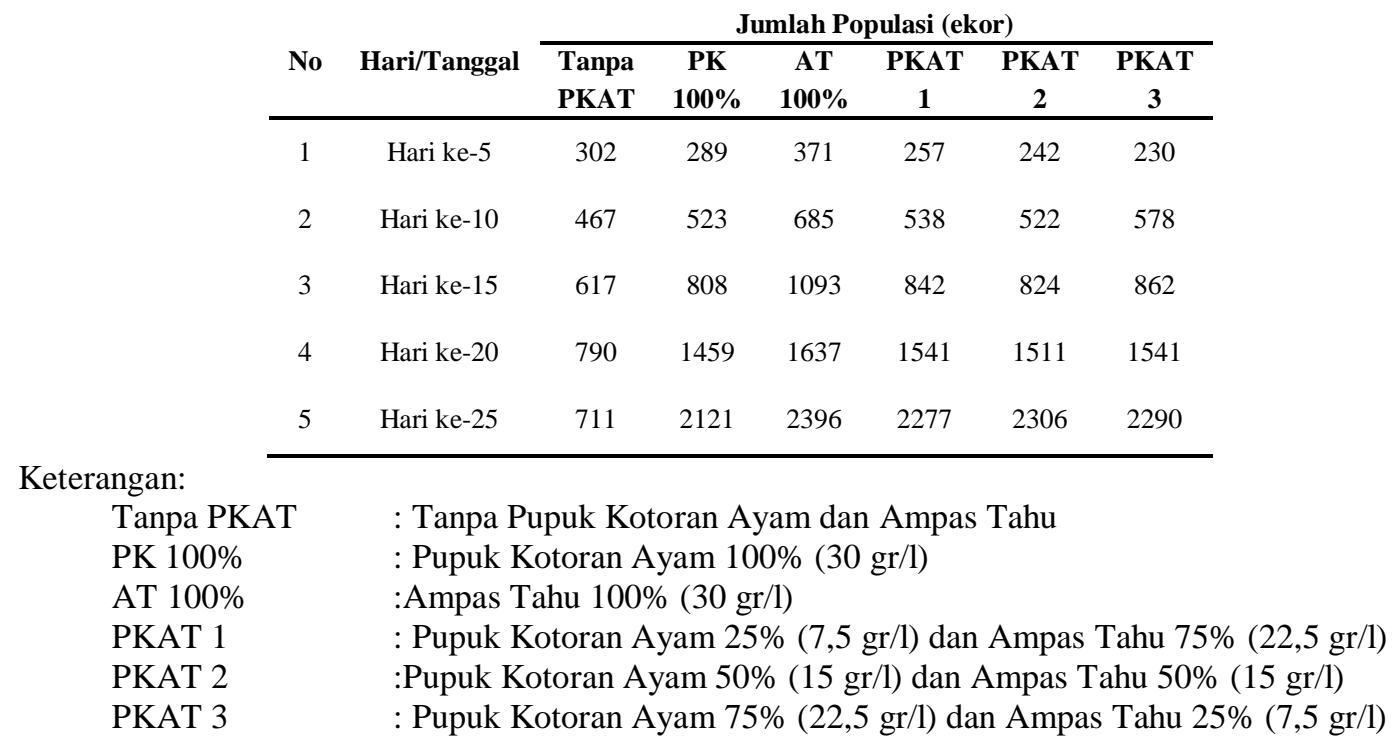

Hasil rata-rata pertumbuhan Daphnia magna pada Tabel 1 menunjukkan bahwa perlakuan tanpa PKAT mencapai puncak populasi di hari ke-20 sebanyak (790 ekor), sedangkan perlakuan AT 100\% (2396 ekor), PKAT 2 (2306 ekor), PKAT 3 (2290 ekor), PKAT 1 (2277 ekor) dan PK 100\% (2121 ekor), mencapai puncak populasi pada hari ke-25. Hal ini sejalan dengan hasil penelitian Ninggar (2016) 
bahwa populasi Daphnia magna terus meningkat dari hari ke hari hingga hari ke-19 pada pemberian pupuk campuran kotoran ayam dan dedak sebanyak 7,5 mg/l dengan jumlah 3113 ekor. Selanjutnya kurva pertumbuhan juga menunjukkan jumlah pertumbuhan populasi (Gambar 1).

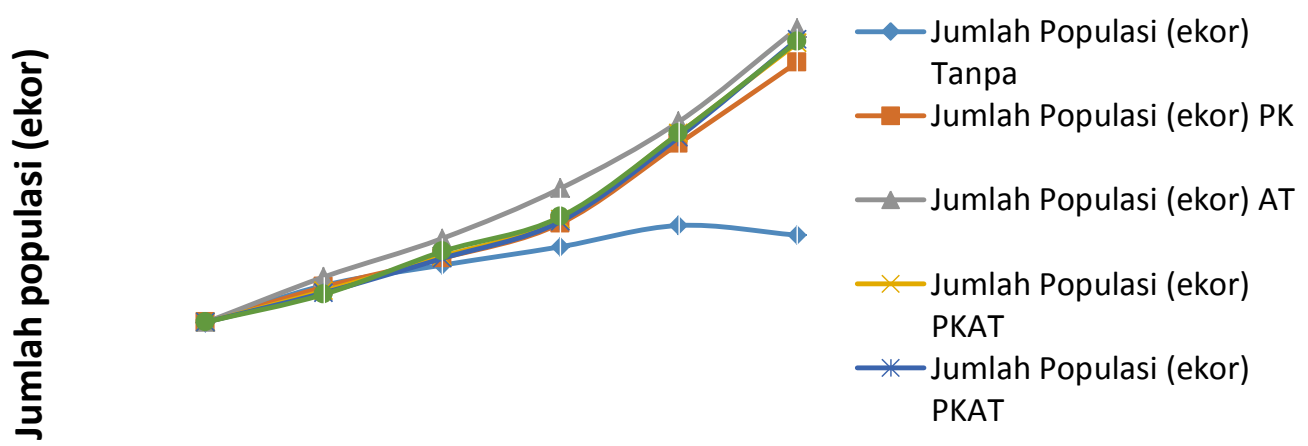

Waktu

Keterangan:

Gambar 1. Kurva Pertumbuhan Populasi Daphnia magna per lima hari.

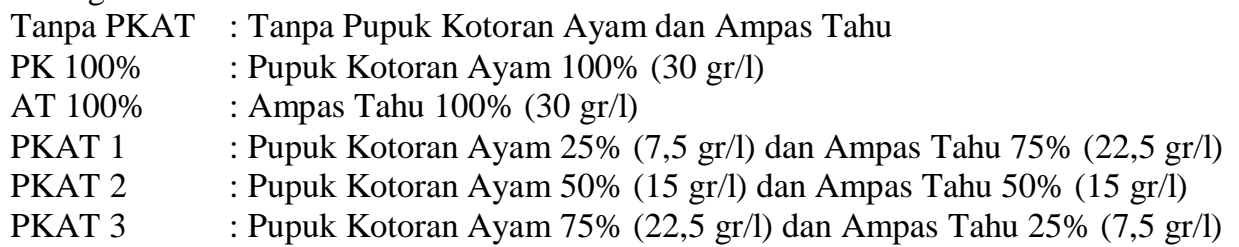

Kurva pertumbuhan populasi pada Gambar 1 menunjukan bahwa perlakuan AT 100\% lebih tinggi pertumbuhan populasinya dibandingkan dengan perlakuan lainnya. Hal ini disebabkan karena ketersediaan pakan yang cukup dalam air dari semua perlakuan, ampas tahu lebih unggul dalam mencapai pertumbuhan populasi karena kandungan nutrisi pada Ampas tahu terdapat protein sebesar $9.6877 \%$ dan lemak sebesar $1.3176 \%$ (Tabel 13) berdasarkan hasil uji proksimat

Tabel 2. Hasil Uji Lanjut Pertumbuhan Populasi Daphnia magna

\begin{tabular}{ccc}
\hline No & Perlakuan & Pertumbuhan Populasi (ekor) \\
\hline 1. & Tanpa PKAT & $722 \pm 45,09 \mathrm{a}$ \\
2. & PK 100\% & $1300 \pm 26,03 \mathrm{~b}$ \\
3. & AT 100\% & $1546 \pm 20,96 \mathrm{c}$ \\
4. & PKAT 1 & $1364 \pm 24,03 \mathrm{~b}$ \\
5. & PKAT 2 & $1352 \pm 14,95 \mathrm{~b}$ \\
6. & PKAT 3 & $1376 \pm 61,77 \mathrm{~b}$ \\
\hline
\end{tabular}


Keterangan : Huruf superscript yang berbeda pada kolom yang sama menunjukkan berbeda nyata $(\mathrm{P}<0,05)$

Tanpa PKAT : Tanpa Pupuk Kotoran Ayam dan Ampas Tahu

PK 100\% : Pupuk Kotoran Ayam 100\% (30 gr/l)

AT $100 \% \quad:$ Ampas Tahu $100 \%(30 \mathrm{gr} / \mathrm{l})$

PKAT $1 \quad$ : Pupuk Kotoran Ayam 25\% (7,5 gr/l) dan Ampas Tahu 75\% (22,5 gr/l)

PKAT 2 : Pupuk Kotoran Ayam 50\% (15 gr/l) dan Ampas Tahu 50\% (15 gr/l)

PKAT 3 : Pupuk Kotoran Ayam 75\% (22,5 gr/l) dan Ampas Tahu 25\% (7,5 gr/l)

Hasil uji lanjut pada Tabel 2 menunjukkan bahwa perlakuan AT 100\% paling banyak populasinya daripada perlakuan Tanpa PKAT, PK 100\%, PKAT 1, PKAT 2, PKAT 3. Hal ini dikarenakan bahwa perlakuan Ampas tahu memiliki persediaan pakan yang cukup dan kandungan nutrisi lebih baik di banding Perlakuan lainnya. Wibowo, et. al., (2014) yang menyatakan bahwa semakin meningkatnya populasi fitoplankton yang ada dalam wadah budidaya maka ketersedian pakan bagi Daphnia sp. tercukupi sehingga pertumbuhan populasi Daphnia sp. juga meningkat.

Pertumbuhan Daphnia magna semakin meningkat dikarenakan air yang sebagai wadah pemeliharaan Daphnia magna mengandung bahan organik yang tersuspensi sebesar 0,0080 - 0,1908 untuk semua perlakuan dan mikroorganisme yang dimanfaatkan sebagai sumber pakan Daphnia magna. Kusumaryanto (2001) menyatakan bahwa Daphnia sp. yang dipelihara dalam air yang mengandung bahan organik tersuspensi dan mineral menyaring dan memakan seluruhnya tanpa membedakan dalam dua jam pertama. Selanjutnya makanan yang ditemukan dalam esophagus hanya partikel organik.

\section{B. Laju Pertumbuhan}

Hasil Uji lanjut Laju Pertumbuhan populasi Daphnia magna disediakan pada tabel 3.

Tabel 3. Hasil Uji Lanjut Laju Pertumbuhan Daphnia magna

\begin{tabular}{ccc}
\hline No & Perlakuan & Laju Pertumbuhan (ekor/hari) \\
\hline 1 & Tanpa PKAT & $0,08 \pm 0,00 \mathrm{a}$ \\
2 & PK 100\% & $0,10 \pm 0.00 \mathrm{~b}$ \\
3 & AT 100\% & $0,11 \pm 0,00 \mathrm{c}$ \\
4 & PKAT 1 & $0,11 \pm 0,00 \mathrm{bc}$ \\
5 & PKAT 2 & $0,11 \pm 0,00 \mathrm{c}$ \\
6 & PKAT 3 & $0,11 \pm 0,00 \mathrm{c}$
\end{tabular}

Keterangan : Huruf superscript yang berbeda pada kolom yang sama menunjukkan berbeda nyata $(\mathrm{P}<0,05$

Tanpa PKAT : Tanpa Pupuk Kotoran Ayam dan Ampas Tahu

PK 100\% : Pupuk Kotoran Ayam 100\% (30 gr/l)

AT $100 \%$ : Ampas Tahu $100 \%$ (30 gr/l)

PKAT 1 : Pupuk Kotoran Ayam 25\% (7,5 gr/l) dan Ampas Tahu 75\% (22,5 gr/l) 
PKAT 2 : Pupuk Kotoran Ayam 50\% (15 gr/l) dan Ampas Tahu 50\% (15 gr/l)

PKAT 3 : Pupuk Kotoran Ayam 75\% (22,5 gr/l) dan Ampas Tahu 25\% (7,5 gr/l)

Hasil laju pertumbuhan pada tabel 3 menunjukan bahwa Perlakuan AT 100\%, PKAT 1, PKAT 2, dan PKAT 3 Lebih baik dari perlakuan Tanpa PKAT dan PK 100\%. Perlakuan PKAT 1 sama dengan PK 100\%. Perlakuan yang laju pertumbuhannya kurang terdapat pada perlakuan Tanpa PKAT sebanyak 0,08 ekor/hari. Hal ini dikarenakan bahwa Perlakuan AT 100\%, PKAT 1, PKAT 2, PKAT 3 lebih baik kandungan nutrisinya daripada Perlakuan Tanpa PKAT dan PK 100\%. Kandungan protein dan lemak sangat berpengaruh terhadap pertumbuhan populasi Daphnia magna. Kandungan protein yang tinggi dan dengan kadar lemak yang sedikit juga akan mempengaruhi pertumbuhan populasi.

Pertumbuhan yang paling terlihat pada perlakuan AT 100\% (30 gr/L). Hal ini diduga karena terjadinya fase pertumbuhan pada Daphnia magna. Zahidah et al., (2012), pertumbuhan Daphnia sp. terdiri dari fase adaptasi, fase eksponensial, fase stationer dan fase kematian. Fase adaptasi merupakan tahap untuk Daphnia magna beradaptasi pada wadah kultur yang baru. Fase adaptasi terlihat hasil yang sama antar perlakuan. Perlakuan Tanpa PKAT, PK 100\%, AT 100\%, PKAT 1, PKAT 2 dan PKAT 3 fase adaptasi berlangsung pada hari ke-0 sampai hari ke-2. Ini menunjukan bahwa Daphnia magna cepat menyesuaikan terhadap wadah kultur yang baru. Setelah fase adaptasi, selanjutnya fase eksponensial.

Fase eksponensial merupakan terjadinya pertambahan jumlah individu beberapa kali lipat dalam jangka waktu tertentu karena adanya siklus reproduksi (Zahidah et al., 2012). Fase eksponensial pada perlakuan Tanpa PKAT terjadi 3 kali yaitu hari ke-5, hari ke-10 dan hari ke-15. Sedangkan pada perlakuan AT 100\%, PK 100\%, PKAT 1, PKAT 2 dan PKAT 3 terjadi 4 kali, yaitu hari ke-5, hari ke-10, hari ke-15 dan hari ke-20. Hal ini diduga karena pada perlakuan tersebut Dahpnia magna dapat memanfaatkan pemupukan dari pupuk kotoran ayam dan ampas tahu secara optimal. Zahidah (2012) menyatakan bahwa dalam kondisi pakan yang cukup maka Daphnia sp. muda (juvenile) akan tumbuh dan berganti kulit hingga menjadi individu dewasa dan bereproduksi secara parthenogenesis, sehingga terjadi penambahan individu beberapa kali lipat. Setelah fase eksponensial selanjutnya fase stasioner.

Fase stasioner merupakan fase puncak populasi (Izzah et.al.,2014). Fase stasioner tertinggi Perlakuan Tanpa PKAT yaitu 987 ekor. ini terjadi setelah hari ke20 perlakuan tanpa PKAT mengalami penurunan populasi. Kemudian perlakuan PK $100 \%$, AT 100\%, PKAT 1, PKAT 2 dan PKAT 3 terjadi puncak populasi pada hari ke-25. Untuk perlakuan PK 100\% yaitu 2651,5 ekor. Untuk perlakuan AT $100 \%$ yaitu 2995 ekor. Untuk perlakuan PKAT 1 yaitu 2846 ekor. Untuk perlakuan PKAT 2 yaitu 2882,25 ekor. Untuk perlakuan PKAT 3 yaitu 2862,5 ekor.

\section{Puncak Populasi}

Hasil Uji lanjut Puncak populasi Daphnia magna dalam penelitian ini dapat dilihat pada Tabel 4. 
Tabel 4. Puncak Populasi Daphnia magna

\begin{tabular}{ccc}
\hline Perlakuan & Hari ke- & Puncak Populasi (ekor) \\
\hline Tanpa PKAT & 20 & $987 \pm 19,44 \mathrm{a}$ \\
PK 100\% & 25 & $2652 \pm 75,90 \mathrm{~b}$ \\
AT 100\% & 25 & $2995 \pm 10,33 \mathrm{c}$ \\
PKAT 1 & 25 & $2846 \pm 105,70 \mathrm{c}$ \\
PKAT 2 & 25 & $2882 \pm 55,04 \mathrm{c}$ \\
PKAT 3 & 25 & $2863 \pm 149,03 \mathrm{c}$
\end{tabular}

Keterangan : Huruf superscript yang berbeda pada kolom yang sama menunjukkan berbeda nyata $(\mathrm{P}<0,05$

Tanpa PKAT : Tanpa Pupuk Kotoran Ayam dan Ampas Tahu

PK 100\% : Pupuk Kotoran Ayam 100\% (30 gr/l)

AT $100 \% \quad$ : Ampas Tahu $100 \%(30 \mathrm{gr} / \mathrm{l})$

PKAT $1 \quad:$ Pupuk Kotoran Ayam 25\% (7,5 gr/l) dan Ampas Tahu 75\% (22,5 gr/l)

PKAT 2 : Pupuk Kotoran Ayam 50\% (15 gr/l) dan Ampas Tahu 50\% (15 gr/l)

PKAT $3 \quad$ : Pupuk Kotoran Ayam 75\% (22,5 gr/l) dan Ampas Tahu 25\% (7,5 gr/l)

Hasil puncak populasi Daphnia magna Pada Tabel 4 menunjukkan bahwa perlakuan AT 100\% (2995 ekor) lebih banyak dibanding dengan perlakuan Tanpa PKAT (987 ekor) dan PK 100\% (2652 ekor) sedangkan perlakuan AT 100\%, PKAT 1, PKAT 2, dan PKAT 3 memiliki jumlah yang tidak jauh berbeda yang artinya sama memiliki populasi terbanyak, tetapi pada perlakuan Tanpa PKAT lebih sedikit dari semua perlakuan. Hal ini sejalan dengan penelitian Ninggar (2016) bahwa populasi Daphnia magna terus meningkat dari hari ke hari hingga hari ke-19 pada pemberian pupuk campuran kotoran ayam dan dedak sebanyak 7,5 mg/l dengan jumlah 3113 ekor.

Menurut Noerdjito (2004) pola pertumbuhan Daphnia sp. ini dipengaruhi oleh beberapa faktor, antara lain kondisi fisik perairan, jenis pakan, dan konsentrasi pakan. Ketika ketiga faktor tersebut mendukung, maka laju pertumbuhan Daphnia sp. akan berlangsung lebih cepat dan menghasilkan puncak populasi yang lebih banyak.

Faktor yang mempengaruhi pola pertumbuhan Daphnia magna:

1. Kondisi fisik perairan

Kondisi air pada penelitian adalah pada perlakuan Tanpa PKAT air yang terdapat didalam akuarium masih berwarna bening dan tumbuh alga hijau sebagai sumber pakan Daphnia magna. Sedangkan perlakuan PK 100\%, AT 100\%, PKAT 1, PKAT 2, dan PKAT 3 kondisi air dalam akuarium berwarna keruh akibat pemupukan dari pupuk kotoran ayam dan ampas tahu. Tetapi kondisi air di dialam wadah akuarium masih mendapatkan cahaya matahari. Kondisi air dalam semua perlakuan yaitu suhu sekitar $24-28^{\circ} \mathrm{C}$. Kisaran tersebut masih dalam batas toleransi untuk pertumbuhan populasi Daphnia sp. menurut Mubarak et al., (2009), temperatur yang baik bagi pertumbuhan dan reproduksi Daphnia sp. berkisar antara $22-31^{\circ} \mathrm{C}$.

2. Jenis pakan

Jenis pakan yang biasa dimakan Daphnia magna adalah mikroorganisme yang tumbuh akibat pemupukan pupuk kotoran ayam dan ampas tahu seperti zooplankton 
dan fitoplankton. Biasanya Daphnia spp. memakan berbagai macam bakteri, ragi, alga bersel tunggal (Chlorella), detritus dan bahan organik terlarut (nutrien) (Rodina dalam Ivleva 1973).

\section{Konsentrasi pakan}

Konsentrasi pakan sangat mempengaruhi pertumbuhan populasi karena pakan adalah salah satu sumber asupan makanan Daphnia magna agar terus tumbuh dan meningkat populasinya. Ketersediaan pakan harus cukup, jangan sampai kurang atau bahkan kelebihan. Kelebihan pakan dalam air dapat mempengaruhi kondisi fisik air seperti amoniak tinggi dan kurangnya oksigen terlarut. Hasil dari pengukuran kualitas dapat dilihat pada Tabel 10.

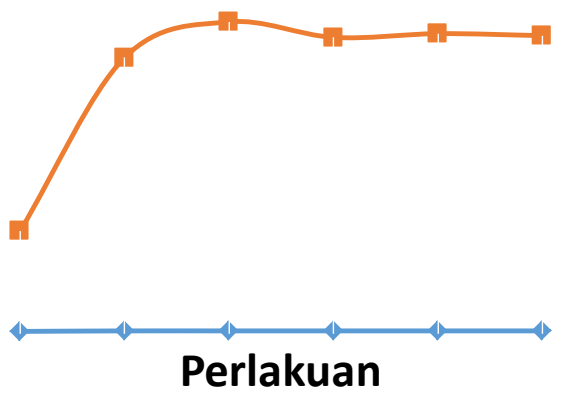

$\multimap$ Hari ke-

- Puncak Populasi (ekor)

Keterangan:

Gambar 2. Grafik Puncak Populasi Daphnia Magna.

Tanpa PKAT

PK $100 \%$

AT $100 \%$

PKAT 1

PKAT 2

PKAT 3

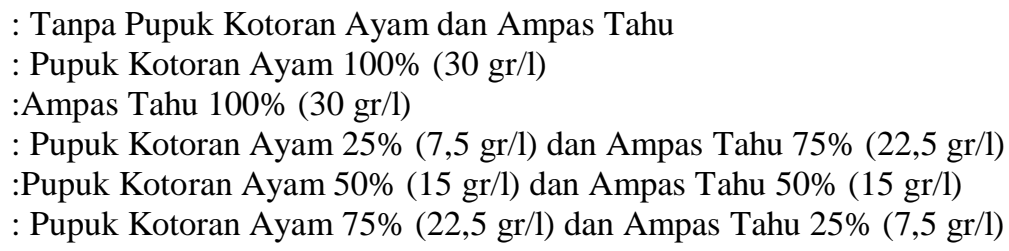

Berdasarkan Gambar 5 menunjukkan bahwa puncak populasi paling tertinggi yaitu pada perlakuan AT 100\%. Perlakuan Tanpa PKAT Berkurang pada hari ke-25, Hal ini disebabkan karena kualitas air dan berkurangnya pakan yang ada dalam badan air . Sedangkan Perlakuan lainnya mencapai puncak populasi pada hari ke-25, ini disebabkan karena kualitas air dan banyaknya persediaan makanan seperti mikroorganisme dalam air.

\section{Pertumbuhan Panjang}

Pengukuran panjang tubuh Daphnia magna dilakukan lima hari sekali. Pengambilan sampel sebanyak 5 ekor dari setiap akuarium. Panjang tubuh Daphnia magna diukur dari ujung anterior sampai dengan akhir posterior dengan menggunakan mistar dalam satuan milimeter $(\mathrm{mm})$. Hasil pengukuran panjang tubuh Daphnia magna dari enam perlakuan (Tanpa PKAT, PK 100\%, AT 100\%, PKAT 1, PKAT 2, PKAT 3) setiap lima hari sekali dan dirata-rata, sehingga didapatkan hasil yang bervariasi sebesar $16-24 \mathrm{~mm}$. Dapat dilihat pada Tabel 6 berikut ini: 
Tabel 6. Pengukuran panjang Daphnia magna per lima hari

\begin{tabular}{|c|c|c|c|c|c|c|c|}
\hline \multirow[b]{2}{*}{$\begin{array}{l}\mathbf{N} \\
\mathbf{0}\end{array}$} & \multirow[b]{2}{*}{ Hari/Tanggal } & \multicolumn{6}{|c|}{ Panjang tubuh $(\mathrm{mm})$} \\
\hline & & $\begin{array}{c}\text { Tanp } \\
\text { a } \\
\text { PKA } \\
\text { T }\end{array}$ & $\begin{array}{c}\text { PK } \\
100 \\
\%\end{array}$ & $\begin{array}{c}\text { AT } \\
100 \\
\%\end{array}$ & $\begin{array}{c}\text { PKA } \\
\mathbf{T} \\
\mathbf{1}\end{array}$ & $\begin{array}{c}\text { PKA } \\
\mathbf{T} \\
\mathbf{2}\end{array}$ & $\begin{array}{c}\text { PKA } \\
\mathbf{T} \\
\mathbf{3}\end{array}$ \\
\hline 1 & $\begin{array}{c}\text { Selasa, } 30 \text { Mei } \\
2017\end{array}$ & 24 & 23 & 23 & 23 & 21 & 24 \\
\hline 2 & $\begin{array}{c}\text { Sabtu, } 3 \text { Juni } \\
2017\end{array}$ & 15 & 16 & 13 & 18 & 16 & 14 \\
\hline 3 & $\begin{array}{c}\text { Kamis, } 8 \text { Juni } \\
2017\end{array}$ & 18 & 17 & 16 & 16 & 15 & 17 \\
\hline 4 & $\begin{array}{c}\text { Selasa, } 13 \text { Juni } \\
2017\end{array}$ & 16 & 18 & 16 & 14 & 16 & 18 \\
\hline 5 & $\begin{array}{c}\text { Minggu, } 18 \\
\text { Juni } 2017\end{array}$ & 16 & 17 & 18 & 17 & 14 & 15 \\
\hline 6 & $\begin{array}{c}\text { Jum'at, } 23 \text { juni } \\
2017\end{array}$ & 16 & 16 & 14 & 14 & 18 & 17 \\
\hline
\end{tabular}

Keterangan:

Tanpa PKAT

PK $100 \%$

AT $100 \%$

PKAT 1

PKAT 2

PKAT 3
: Tanpa Pupuk Kotoran Ayam dan Ampas Tahu

: Pupuk Kotoran Ayam 100\% (30 gr/l)

: Ampas Tahu 100\% (30 gr/l)

: Pupuk Kotoran Ayam 25\% (7,5 gr/l) dan Ampas Tahu 75\% (22,5 gr/l)

: Pupuk Kotoran Ayam 50\% (15 gr/l) dan Ampas Tahu 50\% (15 gr/l)

: Pupuk Kotoran Ayam 75\% (22,5 gr/l) dan Ampas Tahu 25\% (7,5 gr/l)

Keterangan:

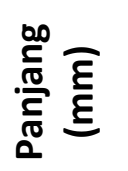

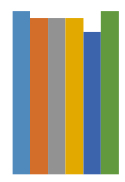
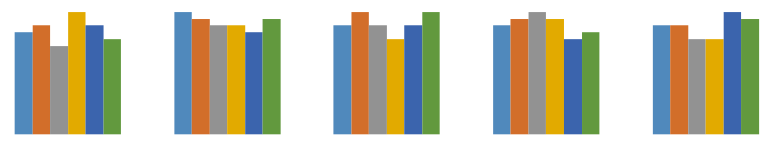

Waktu

Panjang tubuh (mm) Tanpa PKAT — Panjang tubuh (mm) PK 100\%

Panjang tubuh (mm) AT 100\%—Panjang tubuh (mm) PKAT 1

Gambar 3. Grafik Rata-rata Pertumbuhan Panjang Daphnia magna

Tanpa PKAT

PK $100 \%$

AT $100 \%$

PKAT 1

PKAT 2

PKAT 3
: Tanpa Pupuk Kotoran Ayam dan Ampas Tahu

: Pupuk Kotoran Ayam 100\% (30 gr/l)

: Ampas Tahu 100\% (30 gr/l)

: Pupuk Kotoran Ayam 25\% (7,5 gr/l) dan Ampas Tahu 75\% (22,5 gr/l)

: Pupuk Kotoran Ayam 50\% (15 gr/l) dan Ampas Tahu 50\% (15 gr/l)

: Pupuk Kotoran Ayam 75\% (22,5 gr/l) dan Ampas Tahu 25\% (7,5 gr/l)

Berdasarkan grafik pada Gambar 3 diatas bahwa pertumbuhan panjang tubuh Daphnia magna di semua perlakuan menunjukan tidak berbeda nyata. Hal ini disebabkan karena pertumbuhan panjang Daphnia magna tidak dipengaruhi oleh kandungan nutrisi dan jenis pakan yang dimakan dari semua perlakuan. Selanjutnya dapat dilihat hasil uji lanjut pada Tabel 7. 
Tabel 7. Hasil Uji Lanjut Pertumbuhan Panjang Daphnia magna

\begin{tabular}{ccc}
\hline No & Perlakuan & Pertumbuhan Panjang $(\mathrm{mm})$ \\
\hline 1 & Tanpa PKAT & $17,50 \pm 0,58 \mathrm{a}$ \\
2 & PK 100\% & $17,75 \pm 0,50 \mathrm{a}$ \\
3 & AT 100\% & $16,25 \pm 1,26 \mathrm{a}$ \\
4 & PKAT 1 & $16,50 \pm 1,00 \mathrm{a}$ \\
5 & PKAT 2 & $16,25 \pm 0,96 \mathrm{a}$ \\
6 & PKAT 3 & $16,75 \pm 0,96 \mathrm{a}$ \\
\hline
\end{tabular}

Keterangan : Huruf superscript yang berbeda pada kolom yang sama menunjukkan tidak berbeda nyata $(\mathrm{P}<0,05)$
Tanpa PKAT
: Tanpa Pupuk Kotoran Ayam dan Ampas Tahu
PK $100 \%$
: Pupuk Kotoran Ayam 100\% (30 gr/l)
AT $100 \%$
: Ampas Tahu $100 \%$ (30 gr/l)
PKAT 1
: Pupuk Kotoran Ayam 25\% (7,5 gr/l) dan Ampas Tahu 75\% (22,5 gr/l)
PKAT 2
: Pupuk Kotoran Ayam 50\% (15 gr/l) dan Ampas Tahu 50\% (15 gr/l)
PKAT 3
: Pupuk Kotoran Ayam 75\% (22,5 gr/l) dan Ampas Tahu 25\% (7,5 gr/l)

Berdasarkan tabel 7 diatas menunjukkan bahwa hasil uji lanjut pertumbuhan panjang tubuh Daphnia magna tidak berbeda nyata dari semua perlakuan. Ini dikarenakan jenis makanan dan kandungan nutrisi yang ada dalam air tidak mempengaruhi pertumbuhan panjang Daphnia magna. Menurut Aprilian (2014) bahwa Daphnia sp. yang diberi tepung biji kedelai dengan presentase nilai kandungan protein sebesar 53,44\% yang memiliki ukuran tidak jauh berbeda dengan Daphnia sp. yang diberi kotoran ayam dengan presentase nilai kandungan protein sebesar $8,15 \%$ dan tepng ampas kelapa dengan presentase nilai kandungan protein sebesar $14,54 \%$.

\section{E. Uji Proksimat}

Uji Proksimat telah dilakukan di Sekolah Tinggi Perikanan (STP) Jakarta. Hasil uji proksimat akan disediakan dalam Tabel 8 sebagai berikut:

Tabel 8. Hasil Uji Proksimat Pupuk Kotoran Ayam dan Ampas Tahu dalam \% bobot kering

\begin{tabular}{rcccc}
\hline No & Nama sampel & $\begin{array}{c}\text { Protein } \\
(\boldsymbol{\%})\end{array}$ & $\begin{array}{c}\text { Lemak } \\
(\boldsymbol{\%})\end{array}$ & $\begin{array}{c}\text { Abu } \\
(\boldsymbol{\%})\end{array}$ \\
\hline 1 & AT 100\% & 9.6877 & 1.3176 & 21.4908 \\
2 & PK 100\% & 21.9216 & 0.4866 & 2.3800 \\
3 & PKAT 1 & 18.8864 & 1.6344 & 9.8765 \\
4 & PKAT 2 & 14.1905 & 1.1136 & 13.1760 \\
5 & PKAT 3 & 10.1256 & 0.9492 & 13.6743 \\
\hline
\end{tabular}

Keterangan:

PK $100 \%$

AT $100 \%$

: Pupuk Kotoran Ayam 100\% (30 gr/l)

PKAT 1

: Ampas Tahu 100\% (30 gr/l)

PKAT 2

: Pupuk Kotoran Ayam 25\% (7,5 gr/l) dan Ampas Tahu 75\% (22,5 gr/l)

PKAT 3

: Pupuk Kotoran Ayam 50\% (15 gr/l) dan Ampas Tahu 50\% (15 gr/l)

: Pupuk Kotoran Ayam 75\% (22,5 gr/l) dan Ampas Tahu 25\% (7,5 gr/l) 
Hasil uji proksimat pada Tabel 8 menunjukkan bahwa yang paling besar nilai protein ada di perlakuan Pupuk Kotoran Ayam 100\% sebanyak 21.9216\% dan kadar lemak sebesar $0.4866 \%$. Sedangkan kadar protein yang paling sedikit pada perlakuan Ampas Tahu $100 \%$ sebanyak $9.687 \%$ dan kadar lemak sebanyak $1.3176 \%$. Kandungan nutrisi Daphnia bervariasi menurut umur dan tergantung pada makanan yang dimakan. Oleh karena itu dapat dikatakan bahwa protein dan lemak sangat penting untuk pertumbuhan perkembangan Daphnia magna. Pada organisme air yang dibutuhkan sebagai sumber utama untuk menghasilkan tenaga adalah protein, kemudian lemak dan karbohidrat. Kelebihan energi yang dihasilkan dalam proses metabolisme akan disimpan dalam bentuk daging untuk pertumbuhan dan perkembangan kedewasaan (Djarijah, 1995)

Protein yang tinggi dapat dijadikan sebagai sumber nitrogen yang mampu dimanfaatkan mikroorganisme, kemudian mikroorganisme tersebut menjadi sumber makanan bagi Daphnia magna. Sehingga dapat disimpulkan bahwa unsur nitrogen yang terdapat pada protein dapat mempengaruhi pertumbuhan Daphnia magna, semakin tinggi nilai nitrogennya maka semakin tinggi kandungan protein dalam pupuk kotoran ayam, tetapi semakin tinggi kandungan proteinnya maka akan semakin menghambat pertumbuhan populasi Daphnia magna. Hal ini dikarenakan berkurangnya oksigen terlarut dalam air dan kandungan nitrogen yang terdapat pada pupuk kotoran ayam berasal dari feses yang dikeluarkan oleh ayam. Feses ayam terdapat kandungan amoniak yang tinggi sehingga mempengaruhi pertumbuhan Daphnia magna. Smith dalam Subagyo (1981) dalam Ninggar (2016) mengatakan bahwa nitrogen yang dieksresikan lewat urine $75 \%$, sedangkan lewat tinja hanya $25 \%$. Selanjutnya hasil uji proksimat Daphnia magna terdapat pada Tabel 9.

Tabel 9. Hasil Uji proksimat Daphnia magna dalam \% bobot kering

\begin{tabular}{|c|c|c|c|c|}
\hline No & Nama sampel & $\begin{array}{c}\text { Protein } \\
(\%)\end{array}$ & $\begin{array}{c}\text { Lemak } \\
(\%)\end{array}$ & $\begin{array}{l}\text { Abu } \\
(\%)\end{array}$ \\
\hline 1 & Daphnia magna AT & 66.5290 & 8.5346 & 6.1216 \\
\hline 2 & Daphnia magna $\mathrm{PK}$ & 66.8146 & 8.9216 & 8.0376 \\
\hline 3 & $\begin{array}{c}\text { Daphnia magna PKAT } \\
1\end{array}$ & 73.6731 & 7.4214 & 3.4045 \\
\hline 4 & Daphnia magna PKAT & 79.5719 & 6.3659 & 9.8862 \\
\hline 5 & $\begin{array}{c}\text { Daphnia magna PKAT } \\
3\end{array}$ & 81.3061 & 7.3467 & 9.3459 \\
\hline 6 & $\begin{array}{c}\text { Daphnia magna tanpa } \\
\text { PKAT }\end{array}$ & 55.9288 & 7.9433 & 15.1372 \\
\hline
\end{tabular}

Keterangan:

Tanpa PKAT

PK $100 \%$

AT $100 \%$

PKAT 1

PKAT 2

PKAT 3

\author{
: Tanpa Pupuk Kotoran Ayam dan Ampas Tahu \\ : Pupuk Kotoran Ayam 100\% (30 gr/l) \\ : Ampas Tahu 100\% (30 gr/l) \\ : Pupuk Kotoran Ayam 25\% (7,5 gr/l) dan Ampas Tahu 75\% (22,5 gr/l) \\ : Pupuk Kotoran Ayam 50\% (15 gr/l) dan Ampas Tahu 50\% (15 gr/l) \\ : Pupuk Kotoran Ayam 75\% (22,5 gr/l) dan Ampas Tahu 25\% (7,5 gr/l)
}

Hasil uji proksimat Daphnia magna pada Tabel 9 menunjukkan bahwa bahwa populasi terbanyak pada perlakuan AT $100 \%$ dan Paling sedikit pada perlakuan Tanpa PKAT tetapi nilai protein yang paling tinggi ada di perlakuan PKAT 3 sedangkan nilai 
protein AT 100\% sedikit tetapi kadar lemak pada perlakuan AT 100\% lebih besar dibandingkan dengan Perlakuan PKAT 3. Hal ini dikarenakan pertumbuhan Daphnia magna dipengaruhi oleh protein dan lemak. Berdasarkan hasil pengamatan bahwa pertumbuhan Daphnia magna hanya membutuhkan protein sebanyak $66.5290 \%$ dan lemak sebanyak 8.5346\%. Menurut Pangkey (2009) kandungan protein biasanya sekitar 50\% dari berat kering. Pada Daphnia dewasa mengandung lemak yang lebih tinggi dibandingkan pada juvenil yaitu sekitar $20-27 \%$; serta $4-6 \%$ pada juvenil. Pada beberapa spesies dijumpai mengandung protein sampai sebanyak 70\%. Dapat disimpulkan bahwa pada perlakuan PKAT 3 lebih besar daya serap tubuh Daphnia magna sehingga kadar protein yang masuk tinggi tetapi untuk penyerapan kadar lemak kurang, sedangkan pada perlakuan AT 100\% daya serap tubuh Daphnia magna kurang tetapi untuk penyerapan kadar lemak sangat baik.

\section{F. Kualitas Air}

Pengukuran kualitas air dilakukan lima hari sekali. Pengukuran kualitas air ini meliputi Oksigen Terlarut (DO), Suhu, pH dan Amonia (NH3). Kualitas air di sediakan dalam Tabel 10 sebagai berikut:

\begin{tabular}{llll}
\multicolumn{4}{c}{ Tabel 10. Hasil Kualitas Air } \\
\hline No & Kulaitas Air & \multicolumn{1}{c}{ Hasil } & \multicolumn{1}{c}{ Referensi } \\
\hline 1 & $\begin{array}{l}\text { DO } \\
\text { (Dissolved }\end{array}$ & $\begin{array}{l}5,51-9,61 \\
\mathrm{ppm}\end{array}$ & $\begin{array}{l}>3,5 \mathrm{ppm} \text { (Rahayu dan } \\
\text { Andriyani. 2011) }\end{array}$ \\
$\begin{array}{l}\text { Oxygen) } \\
\text { Suhu }\end{array}$ & $24^{\circ} \mathrm{C}-28^{\circ} \mathrm{C}$ & $\begin{array}{l}22-31^{\circ} \mathrm{C} \text { (Mubarak, et } \\
\text { al 2009) }\end{array}$ \\
& pH & $7-9$ & $\begin{array}{l}\text { 6,5 }-9 \text { (Priyambodo dan } \\
\text { Wahyuningsih. 2002) }\end{array}$ \\
4 & Amoniak & $0,10-4,0$ & $\begin{array}{l}0,2 \text { mg/l (Delbaere dan } \\
\text { P. Dhert. 1996) dan }<5 \\
\text { mg/l (Chumaidi dan } \\
\text { Djajadiredja. 1982) }\end{array}$
\end{tabular}

Kisaran tersebut masih dalam batas toleransi untuk pertumbuhan populasi Daphnia sp. menurut Mubarak et al., (2009), temperatur yang baik bagi pertumbuhan dan reproduksi Daphnia sp. berkisar antara $22-31^{\circ} \mathrm{C}$. Kondisi ini masih dalam kisaran yang baik untuk Daphnia sp. Priyambodo dan Wahyuningsih (2002), menyatakan bahwa Daphnia sp. tumbuh baik pada perairan dengan pH 6,5-9. Menurut Rahayu dan Andriyani (2011), Daphnia sp. diketahui toleran dengan kadar oksigen rendah. Untuk dapat hidup dengan baik Daphnia sp. memerlukan oksigen terlarut yang cukup besar yaitu diatas 3,5 ppm. Menurut Delbaere dan P. Dhert (1996), kadar amoniak yang tinggi dapat menurunkan tingkat reproduksi Daphnia. Kadar amoniak yang aman bagi kultur Daphnia adalah di bawah 0,2 $\mathrm{mg} / \mathrm{L}$. Menurut Chumaidi dan Djajadiredja (1982) dalam Ansaka (2002) menyatakan bahwa pertumbuhan populasi dari golongan cladocera akan terhambat danmenurun bila kadar amoniak mencapai 5 $\mathrm{mg} / \mathrm{l} \mathrm{NH} 3-\mathrm{N}$. 
Kualitas air yang tidak mendukung juga mempengaruhi siklus reproduksi Daphnia magna. Terbentuknya anakan jantan menyebabkan perubahan siklus reproduksi Daphnia magna dari aseksual menjadi reproduksi seksual (Ebert, 2005).

\section{KESIMPULAN DAN SARAN}

\section{A. Kesimpulan}

Kesimpulan yang diperoleh dari penelitian ini adalah sebagai berikut:

1) Perlakuan Tanpa PKAT, PK 100\%, AT 100\%, PKAT 1, PKAT 2, dan PKAT 3 sangat berpengaruh berbeda nyata terhadap pertumbuhan populasi dan laju pertumbuhan.

2) Pertumbuhan populasi Perlakuan, Laju pertumbuhan, Puncak Populasi, AT 100\% (Ampas tahu $30 \mathrm{gr} / \mathrm{l}$ ) lebih unggul dari perlakuan lainnya. Secara keseluruhan bahwa perlakuan yang paling baik dalam penelitian ini adalah AT $100 \%$.

3) Hasil Uji proksimat Pupuk Kotoran Ayam yang dikombinasi dengan Ampas tahu yaitu yang paling besar nilai protein ada di perlakuan Pupuk Kotoran Ayam 100\% sebanyak $21.9216 \%$ dan kadar lemak sebesar $0.4866 \%$. Hasil Uji proksimat Kualitas Daphnia magna memiliki protein yang paling tinggi pada perlakuan PKAT 3 yaitu sebanyak 81.3061\% dan kadar lemak sebanyak 7.3467\%.

\section{B. Saran}

Peneliti menyarankan bahwa untuk penggunaan media pemupukan yang lebih efesien (mudah didapat dan murah) adalah ampas tahu. Jadi perlu dilakukan penelitian selanjutnya tentang pemberian pakan Daphnia magna yang dikultur dengan pupuk kotoran ayam dan ampas tahu ke benih ikan.

\section{DAFTAR PUSTAKA}

Aprilian, A. P. 2014. Uji Efiktifitas Pe,berian Kotoran Ayam, tepung Biji Kedelai dan Tepung Ampas Kelapa Terhadap Laju pertumbuhan dan Biomassa Daphnia sp sebagai pakan alami ikan. Skripsi. Universitas Syiah Kuala. Banda Aceh.

Chumaidi dan R. Djayadirejah. 1982. Kultur Massal Daphnia sp. Di Kolam Dengan Menggunakan Pupuk Kotoran Ayam. Buletin Perikanan Darat.

Delbaere, D and P. Dhert. 1996. Cladocerans, Nematodes and Trocophara Larvae. In Manual on Production and Use of Live Food (P. Lavens and P. Sorgelos, ens).

Djarijah, Abbas Siregar. Taken on 17 Oktober 1995. Pakan Ikan Alami. Kanisius. https://books.google.com/books/about/Pakan_Ikan_Alami.html?id=5e5AM8cmG4C. Akses 21 Agustus 2017. Hal 24. 
Ivelva, T.V. 1973. Mass Cultivation of Invertebrates. Biologi and Metods. Translated from Russin. Israel Programe for Scientific Translation. Jerussalem.

Jusadi, Dedi., Dewi Sulasingkin, Ing Mokoginta. 2005. Pengaruh Konsentrasi Ragi Yang Berbeda terhadap Pertumbuhan Populasi Daphnia sp. Departemen Budidaya Perairan, Fakultas Perikanan dan Ilmu Kelautan, Institut Pertanian Bogor. Jurnal Ilmu-ilmu Perairan dan Perikanan Indonesia, Juni 2005, Jilid 12, Nomor 1: 17-21.

Kusumaryanto, H. 2001. Pengaruh Jumlah Inokulasi Awal Terhadap Pertumbuhan Populasi, Biomassa dan Pembentukkan Epipium Daphnia sp. Skripsi. Fakultas Perikanan. Institut Pertanian Bogor.

Mathius, I. W., \& Sinurat, A. P. (2001). Pemanfaatan bahan pakan inkonvensional untuk ternak. Wartazoa, 11(2), 20-31.

Mokoginta, I. 2003. Budidaya Pakan Alami Air Tawar. Modul Daphnia sp. Direktorat Jendral Pendidikan Dasar dan Menengah Departemen Pendidikan Nasional. Bidang Budidaya Ikan Program Keahlian Budidaya Ikan Air Tawar.

Mubarak, S. A. Rinyaning, T. D dan Sulmartiwi, L. 2009. Pemberian dolomit pada kultur Daphnia sp. sistem daily feeding pada populasi Daphnia sp. dan kestabilan kualitas air. Jurnal Ilmiah Perikanan dan Kelautan. 1 (1) : 71.

Ninggar, M. W. 2016. Pengaruh Pemberian Dosis Pupuk Dari Air Endapan Campuran Kotoran Ayam dan Dedak Terhadap Pertambahan Populasi Daphnia Magna. Skripsi. Fakultas Keguruan dan Ilmu Pendidikan. Universitas Sanata Dharma. Yogyakarta.

Noerdjito, D. R. 2003. Optimasi suhu, pH, serta jumlah dan jenis pakan pada kultur Daphnia sp. Sekolah Ilmu dan Teknologi Hayati ITB. Bandung.

Pangkey, H., 2009. Daphnia and Utilization. Jurnal Perikanan dan Kelautan Vol V (3): 33-36.

Putri, Yulia Eka, Niken Ayu Pamukas, Saberina Hasibuan. 2015. Influence Giving Rice Bran Immersion at Chicken Manure Media On The Abundance Daphnia magna. Fisheries and Marine Science Faculty, Riau University.

Zahidah, W. Gunawan, dan Subhan, U. 2012. Pertumbuhan populasi Daphnia sp yang diberi pupuk limbah budidaya keramba jarring apung (KJA) di waduk cirata yang telah di fermentasi EM4. Jurnal Akuatika,3 (1) : 84-94 